Hansen, P. (2016), "The European Union's External Labour Migration Policy; Rationale, Objectives, Approaches and Results, 1999-2014", OECD Social, Employment and Migration Working Papers, No. 185, OECD Publishing, Paris.

http://dx.doi.org/10.1787/5jlwxbxflc0r-en

OECD Social, Employment and Migration Working Papers No. 185

\title{
The European Union's External Labour Migration Policy; Rationale, Objectives, Approaches and Results, 1999-2014
}

\section{Peo Hansen}

JEL Classification: F22, K37, N44

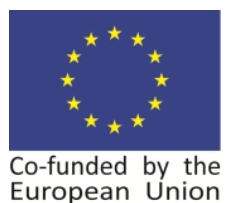


Organisation de Coopération et de Développement Économiques

Organisation for Economic Co-operation and Development

03-Jun-2016

DIRECTORATE FOR EMPLOYMENT, LABOUR AND SOCIAL AFFAIRS

English - Or. English

EMPLOYMENT, LABOUR AND SOCIAL AFFAIRS COMMITTEE

Cancels \& replaces the same document of 04 May 2016

The European Union's External Labour Migration Policy; Rationale, Objectives, Approaches and Results, 1999-2014

Peo Hansen (University of Linköping)

JEL Classification:

F22, N44, K37

This paper is part of the joint project between the Directorate General for Migration and Home Affairs of the European Commission and the OECD's Directorate for Employment, Labour and Social Affairs on "Review of Labour Migration Policy in Europe".

This document has been produced with the financial assistance of the European Union. The views expressed herein can in no way be taken to reflect the official opinion of the European Union.

Grant: HOME/2013/EIFX/CA/002 / 30-CE-0615920/00-38 (DI130895)

A previous version of this paper (DELSA/ELSA/MI(2015)2) was presented and discussed at the OECD Working Party on Migration in June 2015.

Authorised for publication by Stefano Scarpetta, Director, Directorate for Employment, Labour and Social Affairs, OECD.

www.oecd.org/els/workingpapers

JT03397289

Complete document available on OLIS in its original format

This document and any map included herein are without prejudice to the status of or sovereignty over any territory, to the delimitation of international frontiers and boundaries and to the name of any territory, city or area. 


\title{
DIRECTORATE FOR EMPLOYMENT, LABOUR AND SOCIAL AFFAIRS
}

\author{
www.oecd.org/els
}

\section{OECD SOCIAL, EMPLOYMENT AND MIGRATION WORKING PAPERS}

\author{
www.oecd.org/els/workingpapers
}

OECD Working Papers should not be reported as representing the official views of the OECD nor of its member countries nor of the members of the European Union. The opinions expressed and arguments employed are those of the author(s).

Working Papers describe preliminary results or research in progress by the author(s) and are published to stimulate discussion on a broad range of issues on which the OECD works. Comments on Working Papers are welcomed, and may be sent to the Directorate for Employment, Labour and Social Affairs OECD, 2 rue André-Pascal, 75775 Paris Cedex 16, France.

This series is designed to make available to a wider readership selected labour market, social policy and migration studies prepared for use within the OECD. Authorship is usually collective, but principal writers are named. The papers are generally available only in their original language - English or French with a summary in the other.

This document and any map included herein are without prejudice to the status of or sovereignty over any territory, to the delimitation of international frontiers and boundaries and to the name of any territory, city or area.

\section{Applications for permission to reproduce or translate all or part of this material should be made to:}

\author{
Head of Publications Service \\ OECD \\ 2, rue André-Pascal \\ 75775 Paris, CEDEX 16 \\ France
}

Copyright OECD 2016 
DELSA/ELSA/WD/SEM(2016)11

\section{ACKNOWLEDGEMENTS}

I would like to express my gratitude to Jonathan Chaloff for his generous assistance during the completion of this paper. Thanks also to Kees Groenendijk and Jean-Yves Carlier for their valuable comments and suggestions for improvements of the paper. 


\begin{abstract}
This paper is part of the joint project between the Directorate General for Migration and Home Affairs of the European Commission and the OECD's Directorate for Employment, Labour and Social Affairs on "Review of Labour Migration Policy in Europe".

This document has been produced with the financial assistance of the European Union. The views expressed herein can in no way be taken to reflect the official opinion of the European Union.

Grant: HOME/2013/EIFX/CA/002 / 30-CE-0615920/00-38 (DI130895)

A previous version of this paper (DELSA/ELSA/MI(2015)2) was presented and discussed at the OECD Working Party on Migration in June 2015.

This paper presents an overview and analysis of the policy development at the EU level regarding external labour migration (ELM). It reviews the shift in ELM policy at the EU level by examining documents and debates. It looks at the treatment of ELM, setting out from the Amsterdam Treaty and then follows the development up to the present, paying close attention to the evolving rational for increasing ELM. The difference between the horizontal approach and the sectoral approach is explained. The major ELM Directives under the sectoral approach are presented and discussed in terms of how they were negotiated and how they fit into the overall ELM policy strategy. The document concludes by identifying current political challenges for expanding the EU approach beyond its present form.
\end{abstract}




\section{TABLE OF CONTENTS}

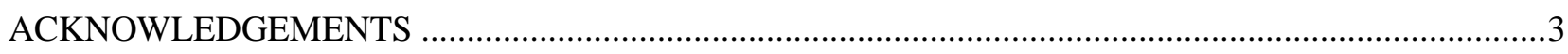

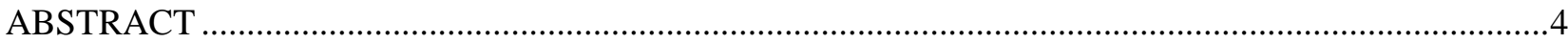

THE EUROPEAN UNION'S EXTERNAL LABOUR MIGRATION POLICY; RATIONALE,

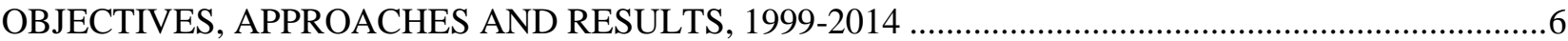

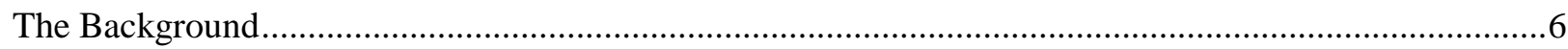

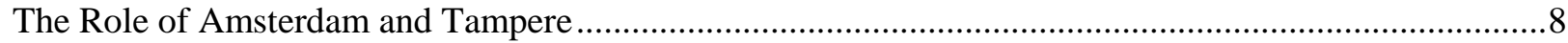

The Commission's Rationale and Objectives for Increasing ELM .......................................................10

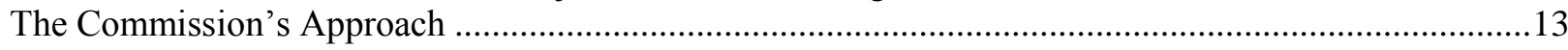

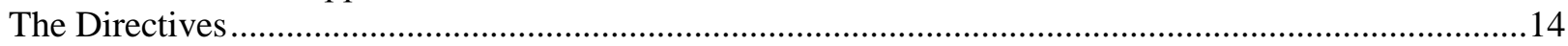

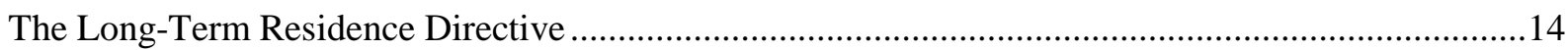

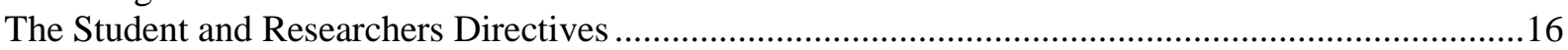

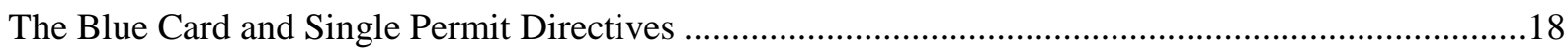

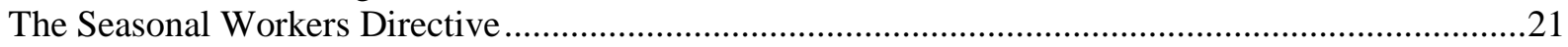

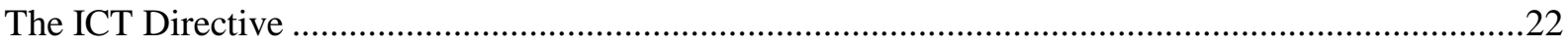

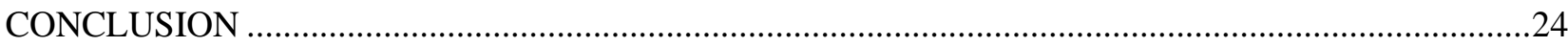

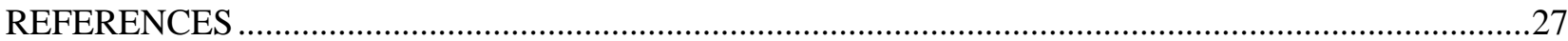




\section{THE EUROPEAN UNION'S EXTERNAL LABOUR MIGRATION POLICY; RATIONALE, OBJECTIVES, APPROACHES AND RESULTS, 1999-2014}

\section{The Background}

1. The EU's declared need for third country labour migrants is not just any type of need. According to most estimates put forward by the EU (but also by the UN and other organizations) the figures range in the tens of millions for the coming five decades. In its 2005 'Policy Plan on Legal Migration', the European Commission (2005a: 4) warns that unless the EU manages to increase labour immigration the EU's working age population is expected to contract by some 52 million by 2050 . Furthermore, as is underscored in the Commission's '2012 Ageing Report', looking only to 2020, the EU would need a net migration of 25 million in order to keep the working-age population stable at current level. This means that the Union would have to net an additional 11 million migrants to the already projected 14 million (EC [European Commission] 2012a: 51-6). This provided, economic growth and migration growth have become two sides of the same coin in the EU's economic and political ambitions. This was made clear already in the Lisbon Strategy (2000-2010) and now constitutes one of the cornerstones of 'Europe 2020', the EU's current ten-year plan for growth (EC 2010a: 18; EC 2011a: 4). From the perspective of the Commission, a large-scale increase in labour migration has become so urgent that the then Home Affairs Commissioner referred to it as a matter of 'our economic survival' (Malmström 2010).

2. The ways in which the EU goes about this urgent undertaking is the topic of this paper. It focuses on the Commission's current approach to external labour migration (ELM), its overarching rationale, core objectives and the practical ways and means by which Brussels seeks to build common EU policy in the area, often against the wishes of intransigent governments in the Council. Consequently, a substantial part of this paper will be devoted to the EU directives relating to ELM that have been adopted so far, accounting for their content as well as analysing how they correspond to the Commission's objectives. 
3. Before saying anything further about the more contemporary developments, however, it is important to take note of the relatively recent nature of the Commission's current position as a strong advocate of ELM, which thus differs from the quite consistent and continuous policy approach that the Commission, since at least the early 1980s, has taken to the three other major areas of migration policy, i.e. asylum, border security/'‘illegal migration' and free movement for EU citizens. From the early 1970s to the late 1990s, and in sharp contrast to today, the Commission instead championed an official line of policy that advised against labour migration to the EU from non-OECD countries. In its 'comprehensive approach' to migration, presented in 1994 (and originally drafted in 1991), the Commission advocated a three-pronged strategy, calling for: (1) 'Taking action on migration pressure'; (2) 'Controlling migration flows'; and (3) 'Strengthening integration policies for the benefit of legal immigrants' (EC 1994: 11).

4. Deemed the only 'realistic' option at the time, this (what is now referred to as) 'zero migration' policy also served as an important public relations tool from the mid-1980s and onwards, promising EU citizens that the transformations brought about by the Single Market would not lead to an increase in external migration (Hansen \& Hager 2012). In an information booklet from 1996, for instance, addressing the 'European citizen', Brussels took care to note that many 'are concerned about immigration [...], thinking that this could increase once internal border controls have been fully swept away'. The question that many EU citizens were asking, according to the Commission, could thus be phrased as follows: 'Will the eventual dismantling of all internal borders lead to an increase in levels of immigration to my country, both from inside and outside the Community?' To this the Commission could give a reassuring answer: 'No, it should not. The fundamental point about dismantling the Community's internal borders is that this process must be accompanied by the synchronized tightening of all external borders' (EC 1996: 13-15).

5. By the turn of the millennium this, by now, habitual policy picture was to be significantly revised. To be sure, the revision did not affect the pursuit of border security, which would continue unabated. But it did involve a remarkable reversal of the EU's stance on ELM. All of a sudden, Brussels would start issuing statements such as the following: 'The Commission considers that the zero immigration mentioned in past Community discussion of immigration was never realistic and never really justified'; and 'it is clear from an analysis of the economic and demographic context of the Union and of the countries of origin, that there is a growing recognition that the "zero" immigration policies of the past 30 years are no longer appropriate' (EC 1999: 2; 2000: 3). 


\section{The Role of Amsterdam and Tampere}

6. This policy shift on ELM formed part of the larger conversion of EU migration policy brought about by the Amsterdam Treaty in 1997 (ratified in 1999) ${ }^{1}$ and the Tampere European Council in 1999, the latter marking the first European Council ever devoted to Justice and Home Affairs (and thus to migration ${\text { issues })^{2}}^{2}$

7. Amsterdam's treaty changes and the bold objectives contained in the multiannual Tampere Programme (1999-2004, resulting from the Tampere European Council) expanded the scope for EU harmonization and supranational provisions with regard to migration policy. Ever since, as seen in the number of directives and other legislation and policy initiatives, this scope has been consistently expanded through Tampere's successor multi-annual programmes, i.e. the Hague (2004-2009) and Stockholm Programmes (2009-2014), the European Pact on immigration and asylum, ${ }^{3}$ and, most crucially, through

1 The Amsterdam Treaty marked a historical shift toward a significantly augmented role for the EU and the supranational level in migration policy. With the overarching aim of developing the European Union as an 'area of freedom, security and justice', Amsterdam laid down the broad outlines for a future EU policy on migration and asylum. Upon ratification, the groundwork for such a policy was to be built incrementally over a period of five years (1999-2004). Some of these changes were spelled out in Article 61 under Amsterdam's new Title IV ('Visas, asylum, immigration and other policies related to free movement of persons', Articles 61-69):

In order to establish progressively an area of freedom, security and justice, the Council shall adopt: (a) within a period of five years after the entry into force of the Treaty of Amsterdam, measures aimed at ensuring the free movement of persons [...] in conjunction with directly related flanking measures with respect to external border controls, asylum and immigration [...] (b) other measures in the fields of asylum, immigration and safeguarding the rights of nationals of third countries.

Further, Article 62 specified that measures should be adopted granting certain limited intra-EU mobility rights to 'nationals of third countries'. In addition, Article 63 outlined a series of measures on asylum and immigration, calling for the adoption (within a period of five years) of a set 'minimum standards' in the area of asylum as well as 'measures on immigration policy within the following areas: (a) conditions of entry and residence, and standards on procedures for the issue by Member States of long term visas and residence permits, including those for the purpose of family reunion, (b) illegal immigration and illegal residence, including repatriation of illegal residents'; and 'measures defining the rights and conditions under which nationals of third countries who are legally resident in a Member State may reside in other Member States.' As part of this reshuffling, Amsterdam also incorporated the Schengen acquis into the treaty framework. As seen, and unlike its predecessor, Amsterdam did not confine itself to immigration and asylum proper, but also introduced into the treaty explicit wordings concerning the Union's resident thirdcountry nationals (TCNs). Moreover, the treaty enacted an article to better equip the Union in its fight against racism and other forms of discrimination. Owing to British, Irish, and Danish opposition, and in order not to derail the negotiations, it became necessary to allow these countries to opt out of these new provisions. Such opt-out, but also opt-in, agreements had to be codified in a series of complex protocols (see Hailbronner 1998; Hedemann-Robinson 1999).

2 At the Tampere European Council in 1999, under the heading 'A Common EU Asylum and Migration Policy', the Council decided that 'a common European asylum system' gradually should be put into operation. Tampere also established that a major focus of the EU's efforts should be on the 'more efficient management of migration flows at all their stages', on more effective external border controls and on combating illegal immigration. In addition, Tampere declared that 'a more vigorous integration policy should aim at granting' third-country nationals 'rights and obligations comparable to those of EU citizens' (European Council 1999).

On the initiative of the French Presidency in 2008 (Council EU 2008). 
the Lisbon Treaty (ratified in 2009), the latter making the Community method of decision and law making applicable also to ELM. ${ }^{4}$ As the Treaty's Title I on 'Common Provisions' (Art. 3) stipulates:

The Union shall offer its citizens an area of freedom, security and justice without internal frontiers, in which the free movement of persons is ensured in conjunction with appropriate measures with respect to external border controls, asylum, immigration and the prevention and combating of crime.

8. In the new Title V, Chapter 2, moreover, the Lisbon Treaty widens Amsterdam's rather limited latitude for immigration policy (as distinct from policies on asylum and illegal immigration) by explicating, in Article 79, that 'The Union shall develop a common immigration policy' and that this should aim at 'ensuring, at all stages, the efficient management of migration flows, fair treatment of third-country nationals residing legally in Member States, and the prevention of, and enhanced measures to combat, illegal immigration and trafficking in human beings'. While the terms 'labour immigration' or 'legal immigration' are not explicitly spelled out in the Treaty, the references to 'common immigration policy' 'management of migration flows' and 'fair treatment of third-country nationals residing legally in Member States' are nonetheless proof of ELM's conditional recognition as a common policy area. Such recognition is also provided by way of emphasizing conditionality, such as in Article 79 and its stipulation: 'This Article shall not affect the right of Member States to determine volumes of admission of third-country nationals coming from third countries to their territory in order to seek work, whether employed or selfemployed.' In emphasizing the conditionality of a 'common immigration policy' the Treaty is also acknowledging that such a policy does, in fact, include ELM, which is contained in the formulation 'in order to seek work'.

9. However, looking at the policy development over the past fifteen years since Amsterdam and Tampere, the achievements with regard to ELM have been both meagre and fragmented. As such, ELM has clearly taken a backseat to the far more prioritized and interrelated areas of 'illegal migration', border security, asylum, visa, return and readmission. ${ }^{5}$

The Community method refers foremost to qualified majority voting in the Council and EP co-decision powers. The Lisbon Treaty also expanded the Court of Justice's say in EU immigration law by, inter alia, giving the EU Charter of Fundamental Rights binding legal status as well as providing for the accession of the EU to the European Convention of Human Rights (see e.g. Douglas-Scott 2011).

It needs mention here that the EU also has sought to gain influence in the area of migrant integration policy, based, initially, on the Amsterdam Treaty's implicit authorization; on Tampere's declaration 'that a more vigorous integration policy should aim at granting' TCNs 'rights and obligations comparable to those of EU citizens' (EC 2001a: 2); the Hague and Stockholm Programmes' as well as Europe 2020's further affirmations; and, finally, the Lisbon Treaty's (first ever) explicit mention of migrant integration as having a legal basis (albeit a very weak one). As stated in Lisbon's Article 79. 4: 'The European Parliament and the Council, acting in accordance with the ordinary legislative procedure, may establish measures to provide incentives and support for the action of Member States with a view to promoting the integration of third-country nationals residing legally in their territories, excluding any harmonisation of the laws and regulations of the Member States.' Apart from non-binding declarations, the adoption of integration principles and agreement on the Commission's role in monitoring and assisting the member states in integration matters (e.g. the 'Common basic principles for immigrant integration policy in the European Union' [see Council EU 2004a; 2004b: 19-20; EC 2005c], and the subsequent 'European Agenda for the Integration of Third-Country Nationals' [EC 2011d]), this policy has not gone beyond supranational measures relating to various types of mobility for resident TCNs within the Union. However, since such integration measures, when being the subject of concrete legislative measures - as seen in several of the directives dealt with in this paper - primarily are framed in terms of labour mobility and less as integration, this paper will group such measures as forming part of EU labour migration and mobility policy rather than EU migrant integration policy. 
The caption of Chapter 2 under Lisbon's Title V, which reads 'Policies on border checks, asylum and immigration', thus serves as an accurate description of the ranking of policy preference within the Council.

\section{The Commission's Rationale and Objectives for Increasing ELM}

10. In this context meagre results of course relate to the Commission's objectives. But what are these more precisely, and how should we construe them in more analytical terms?

11. As already seen, medium and long-term demographic projections constitute the foundation for the Commission's outlook. They have been used consistently throughout as justification of Brussels' stance and to drive home the point that ELM is above all structurally determined and, as such, should not be allowed to be compromised by immediate business cycle and unemployment concerns, but rather needs to be seen as an increasingly urgent necessity in order to sustain growth, competitiveness and social welfare in the EU. Instead of the member states going it alone, devising between themselves inconsistent responses (or few responses at all) at odds with the overall functioning of EU, the Commission approaches these demographically induced migration challenges as calling for common, coordinated and increasingly harmonized policies.

12. From the demographic projections, giving at hand a rapidly aging Union, the Commission then derives in more detail the short, medium and the long-term labour demand with regard to skills required, sectoral assessments and overall structural changes in the labour market. Important to keep in mind is that the Commission does not foresee ELM as the sole solution to the demographic deficit. However, what is interesting is that the Commission is leaning more and more in this direction. For some time, as reflected in the Commission's (2005a: 5) 'Policy Plan on Legal Migration' from 2005, the official view was that 'Immigration does not provide in itself a long-term solution to falling birth rates and an ageing population, but it is one of the available tools within a broader policy mix.' Since then, however, and as seen in numerous statements and documents, not least in the Commission's earlier cited '2012 Ageing Report', ELM is more and more deemed as, if not the only remedy, certainly the most important one, equipped with fairly detailed estimates of the required volumes of migrants and the serious consequences from failure to act in accordance.

13. This tendency is reflected too in Brussels' increasingly alarmist and frustrated calls for member state cooperation on ELM, or as put by the then Home Affairs Commissioner Cecilia Malmström: 'When I meet ministers responsible for labour policies, they almost all speak of the need for immigrant workersand it's true, we need hundreds of thousands, millions in the long term. But when the ministers go and speak in front of their national publics, this message is not to be heard at all.' (quoted in Barber 2011)

14. Besides expanding ELM as such, the Commission also aims to increase the admission of students, researchers and other categories of TCNs more indirectly related to the labour market; this in order to cope with a severe shortage of researchers, in particular, and to facilitate these groups' future labour market participation and contributions to innovation and entrepreneurship, in general.

15. Integral to the goal of increasing ELM is also the goal of increasing the internal mobility of third country labour in the EU. This requires that both long-term resident and newly arrived third country nationals (TCNs) are provided with free movement rights that are more in line with those of EU citizens. For the Commission this is crucial in order to optimize the allocation of labour and to ensure greater flexibility on the EU's labour market.

16. The rationale and goals relating to ELM are embedded in the 'overarching framework of the EU External Migration Policy' (EC 2011b: 5), entitled the Global Approach to Migration and Mobility 
(GAMM), first adopted in 2005 and renewed in 2011, now with a more marked ELM profile. ${ }^{6}$ Here, 'all relevant aspects of migration' are accounted for and brought together into a 'comprehensive', 'coherent' and 'balanced' framework for the purpose of managing migration and mobility to the benefit of both the EU and the sending countries (EC 2011b; 2014d). As one of GAMM's thematic priorities has it:

Good governance of migration and mobility of third countries nationals can create value on a daily basis for the development of millions of people, increase the EU's competitiveness and enrich European societies. This makes the Global Approach a core strategic interest of the EU and its Member States. With an increasingly global labour market for the highly skilled, there is already strong competition for talent. (EC 2011b: 5)

17. GAMM thus explains how to construe the links between ELM and all the other prioritized areas of EU migration policy (i.e. asylum, 'illegal' migration, border security and visa policy); but it also underscores ELM's close alignment with EU foreign and development policy. As such, GAMM contains and seeks to develop in concert everything from supranational legislation and instruments with a firm treaty basis, on the one side, to more loosely defined policy proposals and agreements, unbinding declarations and future plans and visions, on the other.

18. Apart from the work that has gone into specific ELM directives, GAMM reveals the persistent work that the Commission also has invested in furthering the cause of ELM in a number of EU policy processes, collaborations, formalized partnerships, dialogues and negotiations with single third countries, groups of countries, regional and other international organizations. Alongside measure to create cooperation with third countries on 'illegal' immigration, border security, readmission and refugee reception, much effort is thus also devoted to make these compatible with the opening of new and development-enhancing channels for legal labour migration to the EU (EC 2011g).

19. In the wake of the upheavals in North Africa and the war in Libya, EU migration policy activity targeting North Africa has grown exponentially. According to the Commission, the crises and transformations taking place in North Africa have accentuated the need for improved migration management in the Mediterranean area, so as to facilitate, within the GAMM framework, legal migration for North Africans in need of work and to help the EU meet key labour demands and amend its demographic problems. In order to set in train such a mutually beneficial dynamic the Commission proposed, in March 2011, to develop 'a partnership on migration, mobility and security with the Southern Mediterranean countries' (EC 2011c). The focus here is to promote circular labour migration to the EU, built on 'real' and 'clearly identified labour demands', that will 'help to meet the need for highly skilled workers in the expanding sectors of the EU's economy but also help fill many jobs requiring a mix of lower skills' (EC 2011c: 7, 9). The Commission has stepped up these efforts further following the refugee catastrophe at Lampedusa, which gave rise to the Task Force Mediterranean, calling for safe legal migration channels to the EU (EC 2013d).

20. Within various bilateral frameworks sorting under GAMM, such as the European Neighbourhood Policy, the EU-Africa Strategic Partnership on Migration, Mobility and Employment and other partnerships and agreements with third countries, ${ }^{7}$ policies are enacted and developed to facilitate ELM, mostly focusing on so-called circular migration, 'i.e. migrants coming to the EU for short periods and

6 As part of the renewal, the name was also changed from Global Approach to Migration to the current Global Approach to Migration and Mobility.

7 As contained in e.g. the Rabat process for Western Africa; the Prague and Budapest processes; and the negotiations with Turkey and Western Balkans countries. 
going back to a third country after the end of the contract.' (EC 2014b; see also EC 2007c; 2011b). ${ }^{8}$ Among the most important concrete policy instruments in this context are the (bilateral and unbinding) Mobility Partnerships - focusing on effective, secure and flexible management of movement between the EU and third countries - that the EU (to date) has signed with seven third countries, ${ }^{9}$ as well as the Common Agendas on Migration and Mobility (EC 2011c).

21. Yet, when speaking of compatibility between policies on 'illegal' immigration, border security and readmission, on the one side, and ELM, on the other, this should not be understood as a symmetric relationship; rather, it is a highly asymmetrical one where the latter is to be made compatible with the former. This could also be expressed as the golden rule of security-comes-first in EU migration policy, a rule that has been criticised from within the European Parliament and by numerous NGOs and scholars since the supranational level first tried to gain a say over external migration policy in the mid-1980s (see Hansen \& Hager 2012; European Parliament 1990). It should also be mentioned that many analysts assumed that the Commission's new affirmative position on ELM at the turn of the new millennium would (logically) induce a toning down of the strong emphasis on migration security. These hopes, however, where soon frustrated by Brussels' decision to make sure that its repeal of 'zero immigration' was combined with a renewed pledge to EU citizens of strengthening migration security even further. This was visible early on, such as in 2002 when the Commission (2002: 8) pointed to the merits of 'forced return of illegal residents', arguing that this could 'help to ensure public acceptance for more openness towards new legal immigrants against the background of more open admission policies particularly for labour migrants.'

22. Security, then, as in border security, policy to combat 'illegal' migration and the plethora of other migration control instruments developed within the EU framework, serves as the primary rationale and objective that both practically and principally over determines ELM in all its forms, although it is less emphasized in migration policy involving the highly qualified and high-skilled. ${ }^{10}$ As the Commission (2011a: 7) has emphasized on numerous occasions in recent years, the EU must 'ensure that the need for enhanced mobility does not undermine the security of the Union's external borders'; and therefore 'The control of the EU's external border must be continuously improved to respond to new migration and security challenges.' 'Citizens', moreover, 'need to feel reassured that external border controls are working properly', and authorities thus need to demonstrate that ' $[\mathrm{p}]$ reventing irregular migration and maintaining public security are compatible with the objective of increased mobility' (EC 2011a: 7, 11). Or, in a third formulation: 'Without well-functioning border controls, lower levels of irregular migration and an effective return policy, it will not be possible for the EU to offer more opportunities for legal migration and mobility. The legitimacy of any policy framework relies on this.' (EC 2011b: 5, italics in original; see also EC 2014a: 2; Council EU 2012) In its contribution to the UN High-level Dialogue on International Migration and Development in 2013, finally, the Commission (2013a: 4) makes sure to stress that 'In the absence of effective governance, the costs of migration may be significant, and can include social tensions with host populations — often exploited by populist forces - and pressure on scarce resources. Uncontrolled migration may also aggravate security threats'.

$8 \quad$ For in-depth accounts on circular migration as it relates to EU policy, see the contributions in Triandafyllidou (2013); Cassarion (2008); Venturini (2008); Feldman (2012); Carrera \& Hernández iSagrera (2009).

9 These are Moldova, Cape Verde, Georgia, Armenia, Morocco, Azerbaijan and Tunisia.

As indicated in the EU's 'Key messages' to the UN High Level Dialogue on International Migration and Development: 'All states should review existing barriers to human mobility, with a view to remove barriers which are not justified from a security point of view and are unnecessarily hindering economic competitiveness and regional integration' (EC 2013a: 11). 
23. It is crucial to keep in mind, therefore, that whereas migration security constitutes a key objective in and of itself, ELM is always made conditional on security. To the extent that the Commission is determined to create a productive dynamic between the security oriented prevention of illegal immigration, on the one side, and the growth and competitiveness oriented aspiration for a large-scale increase in ELM, on the other, this dynamic needs to be construed as being founded on an asymmetrical relation.

\section{The Commission's Approach}

24. Before turning to the actual legislation that have been achieved up to this point, something should be said too about how the Commission has gone about its task of initiating legislation and getting directives adopted on ELM.

25. Put simply, the Commission has been pursuing two approaches or strategies. The one launched initially, referred to as the horizontal approach, sought to create a broad general common framework for the admission, residence conditions and the rights granted to any TCNs engaging in paid work and selfemployed economic activities. The first major directive proposal on ELM, presented by the Commission in 2001 and drawing on Tampere's mandate, strove for a high level of harmonisation, simplicity, transparency and as little differentiation as possible amongst third country workers - hence the horizontal approach. Basically, TCNs admitted for work in the EU should be treated as one single category and there was also explicit mention of a 'pathway' to permanent residence for those admitted. To be sure, member states were to retain 'the right to limit admission' as well as being provided with other forms of discretion; and the principle of preference of the domestic labour market's workers over TCNs was also to apply (EC 2001b).

26. While the directive proposal was given a favourable response by the European Parliament and the European Economic and Social Committee (EESC), the Council would have none of it; the proposal was, as Peers (2009: 410) puts it, 'dead on arrival in the Council'. ${ }^{11}$

27. But although the horizontal approach had been effectively blocked, this did not prevent the Commission from forwarding new directive proposals. But in the process the Commission's strategy was to change, something that was made official in its 2005 'Policy Plan on Legal Migration' (EC 2005a). The Plan, which was drawn up at the request of the Hague European Council (in 2004), was preceded by the Commission's 'Green Paper on an EU Approach to Managing Economic Migration' (EC 2005b), which presented a set of options for the future development of ELM as well as initiating a public consultation process on this very matter. In the Green Paper the foiled horizontal approach was still presented as one of the options. However, since it was prefaced with the Commission's acknowledgement of having considered the member states' reservations it was clear that it was no longer a viable option, but merely included for the purpose of reaffirming the Commission's preferred approach. In order to break the deadlock with the Council over ELM, the Commission went on to present a sectoral approach as its second main option, and it did so on the merit of having already presented, in 2002 and 2004 respectively, two separate sectoral directives for the entry and residence of third country students and researchers (as discussed below).

28. In the public consultation process on the Green Paper, several of the stakeholders expressed scepticism toward the sectoral approach, cautioning that it would create a differential and fragmented policy picture whereby rules and rights would apply differently and unequally to different categories of TCNs. While the European Parliament's (2005: point 26) resolution advised against a sectoral legislation, the EESC (2005: 4) went further, stating that '[i]f the European Council were to opt for a sectoral approach (geared towards highly skilled migrants), it would be discriminatory in nature.'

11 The directive proposal was officially withdrawn in 2006. 
29. Such objections notwithstanding, the Policy Plan on Legal Migration confirmed the sectoral approach as the Commission's new strategy, one it, in actuality, had already embarked on in the student and researchers directives. More specifically the Policy Plan outlined a roadmap for the next four years, specifying that the Commission's priority would be to table five directives in all, four of which were to address sector specific categories of migrants (highly skilled, seasonal, intra-corporate transferees and remunerated trainees, as attended to below). In addition to this there would also be a proposal for a framework directive (or single permit) defining basic rights for labour migrants (EC 2005a).

30. In what follows these and other directives ( 9 in total $)^{12}$ relating to ELM are discussed, focusing both on their specific content and goals, as well as how they measure up to the Commission's more general and overarching rationale and objectives.

\section{The Directives}

\section{The Long-Term Residence Directive}

31. As already noted, the Commission proposed directives relating to ELM prior the 2005 Policy Plan; and although the failed horizontal proposal from 2001 counts as the first substantial one, important ELM components were also included in the even earlier directive proposal (March 2001, EC 2001a) concerning the status of third country nationals who are long-term residents, which was adopted in November 2003. The Directive (Dir. 2003/109/EC) ${ }^{13}$ establishes the conditions under which a member state confers (and revokes) long-term resident status and accompanying rights to legally resident TCNs. ${ }^{14}$ Most importantly for the purposes here, the directive also lays down the rules concerning the rights of residence for TCNs in member states other than the one that has granted them long-term resident status.

32. As stipulated in the directive, the status of long-term resident should be given to applying TCNs 'who have resided legally and continuously' in a member state for five years. Other key requirements specify that TCNs must demonstrate 'stable and regular resources' that are adequate to support themselves and their family dependants, 'without recourse to the social assistance system of the Member State concerned'; that they have sickness insurance; and that they abide by national integration obligations where such apply.

33. While this directive does not speak directly to the Commission's objective of increasing ELM-it exclusively addresses the conditions for TCNs already residing in the EU-it aligns very well with Brussels long-standing goal of closing the rights and labour mobility gap between member state nationals, or EU citizens, and legally resident TCNs. This goal has been on the Commission's agenda since the early 1970s, as seen in these strong wordings from 1974:

12 With one exception, all of the directives discussed here have been adopted; the ones on seasonal migration and ICTs are still awaiting transposition. The one exception concerns a directive incorporating remunerated trainees; this category is currently incorporated in a directive proposal, still under negotiation, 'on the conditions of entry and residence of third-country nationals for the purposes of research, studies, pupil exchange, remunerated and unremunerated training, voluntary service and au pairing' (EC 2013b).

Council Directive 2003/109/EC of 25November 2003 concerning the status of third-country nationals who are long-term residents. The UK, Ireland and Denmark do not take part in this directive.

As of 2013, according to Eurostat, TCNs made up 4 per cent of the EU's population (or 20.4 million) (EC 2014b: 3). 
[T] he legal situation of migrant workers coming from third countries depends on the status accorded to them by the host country. [...] The result is that migrant workers from third countries are generally treated less favourably than workers coming from the Member States, and the situation of these third country migrants varies considerably from one country to another. [T] he social conditions of the migrant do indeed give cause for serious concern - especially in the case of third country migrants, who have no Community protection and rely solely on often restrictive national legislation [...] For this reason solutions in common must be found, not only to the problems of Community migrants but also for those from third countries. These solutions must take account of the migrant workers' needs and their rightful place in a society to whose prosperity and well-being they contribute. As the migrant population increases, and they remain longer in the Community, so their interests in the affluent society around them increases and their sense of exclusion from it can become more acute (EC 1976 [1974]: 14, 12).

34. Thirty years later the Commission's perseverance can be said to have borne some fruit in the long-term resident directive (LTR), which was made possible by the Amsterdam Treaty's Article 63, the Tampere European Council and the Tampere Programme's commitment to 'safeguarding the rights of third country nationals'.

35. The pledge to improve the lot of the EU's legal and permanently settled TCNs was clearly one of the boldest declarations made in Tampere and, as such, it is asserted in the preambles to all but one of the directives discussed in this paper; in most of them, moreover, 'the protection of the rights of third-country nationals' appears in the preamble's first recital. By stating that 'a more vigorous integration policy should aim at granting them [TCNs] rights and obligations comparable to those of EU citizens', the Council opened up for a revision of the legal restraints built into the EU citizenship that was instituted by the Maastricht Treaty. It must be emphasized, though, that neither Amsterdam nor the declarations in Tampere indicated that permanently settled TCNs were about to become naturalized EU citizens any time soon, or, for that matter, that long-term residence was about to replace nationality as the determining principle of EU citizenship (Kostakopoulou 2002: 452). This provided, the strategy adopted by the Commission since then, and as clearly reflected in the LTR directive, has rather been geared toward making the most of Tampere's pledge to grant rights to TCNs that are 'comparable to those of EU citizens'.

36. To improve TCNs' intra-EU mobility rights is of course crucial to this strategy. 'A genuine area of freedom, security and justice', the Commission (EC 2001a: 8) affirmed in the LTR directive proposal in 2001, 'is unthinkable without a degree of mobility for third-country nationals residing there legally, and particularly for those residing on a long-term basis'. With the adoption of the LTR directive, then, the Commission gained (somewhat of) a hearing for its repeated calls for facilitating TCNs' intra-EU mobility and residence.

37. The Commission's attempt to expand the scope of free movement to also incorporate TCNs must be understood in the context of its perpetual mission to stimulate labour mobility within the EU area. In the LTR directive proposal the Commission contended that to continue barring legally resident TCNs from the free movement provisions runs counter to 'the demands of an employment market that is in a process of far-reaching change, where greater flexibility is needed' (EC 2001a: 8):

The evolution of the employment market in the Union is highlighting employment shortages in certain sectors of the economy. Third-country nationals who are long-term residents may be ready and willing to relocate either in order to put their vocational skills to work in another Member State or to escape unemployment in the Member State where they reside. The mobility of long-term residents can thus make for better utilisation of employment reserves available in different Member States (EC 2001a:8). 
38. It is in this larger context that the objectives of the LTR directive (and subsequent directives that similarly seek to facilitate TCNs' intra-EU mobility) need to be situated; or as stated in the LTR directive's preamble: 'It could also constitute a major factor of mobility, notably on the Union's employment market.' Permanently settled TCNs constitute an untapped labour reserve that, once unhampered by the EU's internal borders, could help remedy recurrent labour shortages in growth industries and other labour market distortions across the Union. Moreover, since TCNs suffer disproportionately from unemployment, the Commission seems to presume they should be more prone (given their weaker bargaining position) to intra-EU labour mobility than are member state nationals. As such, the LTR directive does, in fact, indirectly promote the goal of increasing ELM, both by providing for mobility within the EU that could increase third country labour flows to some member states (that might suffer comparatively more from labour shortages and demographic imbalances) and by enabling onward movement of third country labour migrants from member states with more open ELM policies (and thus higher inflows) to members with more restrictive policies; in the latter case the directive would have a positive impact on absolute numbers.

39. Yet, it needs emphasizing that the mobility rights offered to TCNs by the LTR directive are nowhere near those contained in EU citizenship provisions; also, the directive was a far cry from the Commission's original proposal for such a directive (as tabled in 2001), which aimed to provide TCNs with more rights. As with all the directives covered in this paper, moreover, the LTR directive is fraught with exceptions and red-tape, and with regard to rights and equal treatment for the long-term resident TCNs numerous disparities prevail, both as concern the situation in the granting member state and the conditions applying to a long-term resident who wishes to move to another member state. In the latter case, just to point to one of many derogations, non-granting member states are allowed to 'limit the total number of persons entitled to be granted right of residency' (Art 14: 4), a derogation highlighting member states' refusal give a blank cheque to TCNs' intra-EU movement. Reflecting the fragmented and stratified scope, which in turn results from the failure of adopting a more horizontal approach (as discussed above), the directive exempts no less than six categories of TCNs from its provisions. In 2011 the Commission managed to have the directive amended in order 'to extend its scope to beneficiaries of international protection' (Dir. 2011/51/EU), ${ }^{15}$ a category who is now also eligible for long-term resident status.

\section{The Student and Researchers Directives}

40. Adopted a year after the LTR directive, the so-called Student Directive (Dir. 2004/114/EC) ${ }^{16}$ also deserves mention here. As with the former this directive is neither explicitly tied to the goal of increasing and facilitating ELM; in fact, it is explicitly dissociated from 'the labour-market situation in the host country'. Yet, since it concerns itself with (treaty and Tampere) provisions directly pertaining to the 'approximation' of the member states' rules on admission and residence of TCNs as well the improvement of TCNs' situation in the EU, it is clearly worth consideration in the wider ELM context. Not the least due to the obvious fact that third country students who have their foot inside the door very well might be recruited for work in the EU at a later stage.

41. Setting out from the broad objectives of championing the EU as an educational 'world centre of excellence' and promoting third country student mobility to the EU, the immediate purpose of the directive is to create a common legal framework defining the conditions and procedural rules for admission of TCNs to the EU 'for a period exceeding three months for the purpose of studies, pupil exchange, unremunerated training or voluntary service'. Whereas the directive 'shall apply' to TCNs who apply for purposes of study

15 Directive 2011/51/EU of the European Parliament and of the Council of 11 May 2011 amending Council Directive 2003/109/EC to extend its scope to beneficiaries of international protection.

Council Directive 2004/114/EC, of 13 December 2004, on the conditions of admission of third-country nationals, for the purposes of studies, pupil exchange, unremunerated training or voluntary service. The UK, Ireland and Denmark do not take part in this directive. 
(i.e. higher education), member states 'may also decide' to have the other activities fall within the directive's scope. As part the wider focus on mobility, the directive stipulates that students who apply to conduct a part of their studies at a higher education establishment in a member state other than the one they were first admitted to 'shall be admitted' to that member state in due course and pending certain conditions. Equally relevant in this context, and notwithstanding the preamble's explication that the directive's migration provisions are not conditioned by 'the labour-market situation in the host country', is the fact that 'students shall be entitled to be employed and may be entitled to exercise self-employed economic activity' (Art. 17). To be sure, however, member states are allowed to impose a number of restrictions in this area.

42. Closely related to the Student Directive, the so-called Researchers Directive (Dir. 2005/71/EC) ${ }^{17}$ was adopted in October 2005. Aiming to attract third country researchers to the EU and forming an integral part of the creation of a European Research Area and the Lisbon Strategy's goal of turning the EU into 'the most competitive and dynamic knowledge-based economy in the world by 2010', this directive was also launched for the more particular purpose of contributing to the target (set in 2003) of having an additional 700000 researchers working in the Union by 2010 (via a goal of earmarking 3\% of GDP for investment in research).

43. Conditional on a hosting agreement with a research organization, the directive establishes the (simplified) admission terms for researchers from third countries who are to carry out research in a member state for more than three months. The researchers are granted rights comparable to those of member state nationals in a number of areas (much in line with the LTR directive), but in contrast to students and doctoral students (under the Student directive) they are afforded more favourable intra-EU mobility rights and they are afforded both family reunification and EU mobility for family members (neither of these apply to students). As Chou (2012: 1062) notes, moreover, and contrary to future ELM directives (e.g. the Blue Card directive), the principle of Community preference, or labour market test, does not apply to the directive.

44. Although third country researchers, as by definition, always will involve relatively few people, this directive nonetheless answers directly to the Commission's goal of increasing ELM, at least in the high-skilled category; this too, since it exclusively addresses third country nationals (and their family members) who will migrate to the EU, as opposed to TCNs who are already EU residents. Together with the student directive it is also of some principal and symbolic importance since it conforms to the Commission's long-standing goal, dating to the Single Market relaunch in the early 1980s (Geddes 2000: 70), of supranational harmonization of migrant admission policies.

45. Both of these directives should have been transposed into national law in 2007; however, more than half of the members failed to do so, prompting the Commission to issue infringements proceedings. In the subsequent reports on the application of the directives, both of which were published in 2011, the Commission voiced its dissatisfaction with the performance of the directives (EC 2011e; 2011f). Among other things, the Commission drew attention to the dismally low number of third country researchers that had been admitted under the researchers directive.

46. In the spring of 2013, therefore, the Commission decided to table a proposal to amend both directives and merge them into one directive, calling for improvements and additions regarding a number of key components, such as admission procedures, rights, intra-EU mobility, number of binding rules and overall coherence. Most of all, the Commission (2013b) intends to make the directives more compatible

17 Council Directive 2005/71/EC of 12 October 2005 on a specific procedure for admitting third-country nationals for the purposes of scientific research. The UK and Denmark do not take part in this directive. 
with the Europe 2020 Strategy and the EU's Global Approach to Migration and Mobility (GAMM), 18 highlighting the ever-increasing importance of attracting talented third country students and researchers to the EU. The directive proposal also sounds the alarm over the EU's alleged 'innovation emergency' vis-àvis the US and Japan, its shrinking working age population and structural demographic and economic challenges that risk to grow worse unless the EU manages to compete successfully for global talent: 'Thousands of the best researchers and innovators have moved to countries where conditions are more favourable' (EC 2013b: 2).

47. The proposal is also much more explicit than the two original directives in its emphasis on the labour migration aspect: 'One of the key elements of this proposal would be to better tap into the potential of students and researchers upon finalizing their studies/research. They constitute a future pool of highly skilled workers as they speak the language and are integrated in the host society.' (EC 2013b: 8) The amended directive thus intends to provide students with more possibilities to work while studying as well as giving both students and researchers the right, upon completion of their studies/research, to stay for an additional 12 months in order to seek work and to start a business. As in the case of the amended LTR directive above, the proposal adds new categories of TCNs to be covered by the directive's admission conditions. These are labour migrants admitted to work as au pairs and remunerated trainees ${ }^{19}$ thus again evincing the directive's ELM focus. In addition to this the amended directive proposes to extend and improve the intra-EU mobility and labour market access terms for family members of third country researchers; and it facilitates mobility for students and researchers.

\section{The Blue Card and Single Permit Directives}

48. The Blue Card Directive (Dir. 2009/50/EC), ${ }^{20}$ which was adopted in May 2009 to attract highly qualified labour migrants to the EU, is arguably the EU's most publicly well-known labour migration directive to date, immediately acquiring a flagship status due to the fact that the Commission finally could point to an instrument with a potential (at least ostensibly) to involve fairly large number of new labour migrants. Indeed, when the European Parliament, in the autumn of 2008, overwhelmingly approved the Commission's Blue Card proposal, the then EU Home Affairs Commissioner, Jacques Barrot, translated the Parliament's approval as clearly indicating 'that Europeans are open to immigration flows and that we are welcoming to nationals from outside Europe' (quoted in Goldirova 2008).

49. Building on the Amsterdam Treaty and the Hague Programme's provisions and tailored to amend projected labour and skills shortages and to the Lisbon Strategy, the directive lays down the terms of entry, residence and intra-EU mobility for highly qualified third country workers and their families. As with the LTR and researchers directives it stipulates socio-economic rights in a number of areas as well as a set of labour rights, in accordance with the goal of approximating the rights of TCNs with those of member state nationals. The directive explicitly seeks to encourage circular migration between countries of origin and the EU, but it also provides a path to long-term resident status in the EU, in keeping with the rules of the LTR directive.

18 As part of GAMM, the European Neighbourhood Policy (ENP) and the bilateral Mobility Partnerships signed with a growing number of non-EU countries are specifically mentioned as means by which the EU could increase its intake of researchers and students.

The inclusion of remunerated trainees responds to the 2005 Policy Plan's roadmap for sectoral directives.

Council Directive 2009/50/EC of 25 May 2009 on the conditions of entry and residence of third-country nationals for the purposes of highly qualified employment. The UK, Ireland and Denmark do not take part in this directive. 
50. While the directive is promoted for its rights provisions and commitment to making the EU most attractive destination for highly qualified migrants, it also contains numerous complicated requirements and restrictions as well as many discretionary and derogative powers for the member states, the latter, of course, a sine qua non for making the adoption of the directive possible in the first place. Due to this, as many scholars have pointed out, the directive's facilitating impact on the harmonization of the different member states' admission systems, which made up one of the Commission's main rationales for the Blue Card in its original directive proposal (EC 2007b: 3), can only be meagre at best. ${ }^{21}$ As Eisele (2013:2) puts it, by failing to phase out the 28 different national systems for qualified third country workers, as originally intended, the Blue Card directive can best be likened to 'an upgraded national residence and work permit'.

51. Many limitations also apply to intra-EU mobility, another of Brussels' key motivations for launching the Blue Card proposal. ${ }^{22}$ As Article 18 has it, before a Blue Card holder and his/her family 'may move to' another member state, the card holder must have resided at least 18 months in the first member state. Yet as the 'may' clause indicates (and the directive contains many of these), even then their intra-EU mobility is not guaranteed, since the directive specifies that 'Member states may continue to apply volumes of admission as referred to in Article 6'. As Article 6 establishes, restating the treaty's Article 79, this directive 'shall not affect the right of a Member State to determine the volume of admission of third-country nationals entering its territory for the purposes of highly qualified employment.' This is of course the most crucial impediment to making due on the Commission's main objective of stimulating a large increase in ELM; at the same time this was made clear by the Commission already when it presented its proposal in 2007, the press release stating that the directive 'does not create a right of admission; and is demand-driven, i.e. based on a work contract. Member States will therefore maintain control on which type — and on how many-highly qualified workers will enter their labour markets' (EC 2007a: 2; see also EC 2007b: 7). In effect, this means that member states retain the option of not issuing any Blue Cards at all, thus defeating the purpose of the directive. In a nutshell, this illustrates just how contentious the issue of EU harmonization of ELM is in the EU, with member states showing little interest in ceding control, particularly when it comes to the key matters of admission, access to labour markets and volumes of labour migrants.

52. In its '5th Annual Report on Immigration and Asylum (2013)', published in May 2014, the Commission (2014b: 13) takes note of the low number of Blue Cards being issued so far: 3644 in total for 2012, of which Germany stood for 2584. As a tentative explanation, the Commission, in its implementation report from May 2104, points to the already operating and competing national systems for high-skilled migration, defective transposition of the directive, 'the low level of coherence, the limited set of rights and barriers to intra-EU mobility' as well as to poor information (EC 2014c: 10).

53. In this context mention should also be made of the Single Permit Directive, or the Framework directive (Dir. 2011/98/EU), 23 which was launched alongside the Blue Card directive proposal in 2007 (EC 2007d). Of the directives dealt with here, this was the first to be adopted under the Lisbon Treaty and thus

$21 \quad$ For more on the limited scope and impact of the Blue Card, see e.g. the contributions in Grütters and Strik (eds, 2013); Cerna (2014); Gümüs (2010); Peers (2009).

As stated by the Commission (2007: 6) in the directive proposal: 'Intra-EU mobility would be a strong incentive for third-country highly qualified workers to enter the EU labour market, and could play a primary role in relieving the labour shortages in certain areas/sectors.'

Directive 2011/98/EU of the European Parliament and of the Council of 13 December 2011 on a single application procedure for a single permit for third-country nationals to reside and work in the territory of a Member State and on a common set of rights for third-country workers legally residing in a Member State. The UK, Ireland and Denmark do not take part in this directive. 


\section{DELSA/ELSA/WD/SEM(2016)11}

in accordance with the Community method and its full parliamentary co-decision powers. ${ }^{24}$ Since the proposal was met with much objection from member states in the Council and also subject to ample disagreement within the Parliament-which at first (in 2010), and in part due to the directive's sectoral approach, voted to reject the proposal-and, subsequently, between the Council and the Parliament, a significantly altered directive was only adopted in December 2011, after more than four years of protracted negotiations.

54. With reference to the Lisbon Treaty's Article 79(2) and the objectives of the Tampere European Council and the Stockholm Programme, the directive lays down 'a single application procedure for issuing a single permit for third-country nationals to reside for the purpose of work in the territory of a member state'; and it establishes 'a common set of rights of third-country workers legally residing in a Member State, irrespective of the purposes for which they were initially admitted' (Art. 1). Explicitly steering clear of any bearing upon 'the admission, including the volumes of admission, of third country nationals for the purposes of work', the directive's first subject matter relates exclusively to provisions whereby TCNs (or their employers) enter into a single application procedure that, in turn, should a member state grant admission, results in a 'combined title' covering both residence and work permits 'within a single administrative act'.

55. The aim is thus to contribute to procedural simplification, greater efficiency and harmonization of national rules, something that is said to facilitate control of migration and the legality of migrants' stay in the EU. As to the second subject matter, regarding rights, this reiterates Tampere's, but also the Stockholm Programme's, pledge to ensure fair treatment of TCNs and rights that are comparable with member state nationals. In the preamble the objective of 'narrowing' the so-called 'rights gap between citizens of the Union and third-country nationals legally working in a Member State' is elaborated in some detail. The directive establishes that third country workers who have been granted single permits will enjoy a set of equal treatment rights comparable to those of EU citizens (Art. 12; e.g. working conditions, freedom of association, branches of social security and tax benefits), yet not on a par with those afforded under the Blue Card and LTR directives. In essence, and as stated in the preamble, the rights under the single permit directive are specifically, although not exclusively, intended for third country workers 'who are not yet long-term residents' (recital 19) and thus not eligible for the LTR directive's provisions. As also stated in the preamble, and provided 'the absence of horizontal legislation', this is done in order 'to developing further a coherent immigration policy and narrowing the rights gap' between TCNs and EU citizens.

56. These ambitions notwithstanding, the single permit directive may be the most conspicuous illustration so far of the disjointing effects stemming from 'the absence of horizontal legislation'. To begin with, the directive lists no less than 12 categories of TCNs to whom the directive 'shall not apply' (Article 3); some of these, but far from all, are covered by more favourable terms in previous directives. As numerous scholarly accounts point out, moreover, member states managed to not only reduce the scope and binding force of the directive; they also procured ample room to manoeuvre within what was left in the directive, including significant latitude for interpretation, national law involvement and restrictions of rights for TCNs (Brinkmann 2012; Groenendijk 2013; Peers 2012a). As Brinkmann's (2012: 365-6) detailed study concludes, then, the directive can have 'only a limited harmonising effect' (see also Pascouau \& McLoughlin 2012). The transposition date for the single permit directive was set for 25 December 2013. Yet, as the Commission noted in its Annual Report (2014b: 14), by the end of 2013 only 8 members had complied, prompting the Commission to open infringements proceedings.

24 Initially, the directive had its legal basis in the old Article 63, when the Community method did not apply, but since it had not been adopted when the Lisbon Treaty (and the full scope of the Community method) entered into force in December 2009, its legal basis was changed to Article 79. 
DELSA/ELSA/WD/SEM(2016)11

\section{The Seasonal Workers Directive}

57. After nearly four years of negotiations, the Seasonal Workers Directive (Dir. 2014/36/EU) ${ }^{25}$ was adopted in February 2014. It specifies the terms of entry, stay and rights of TCNs who apply to be employed as seasonal labour in the EU for a maximum stay of between five to nine months within a 12month period. Although the directive leaves decisions about volumes of seasonal labour to be admitted exclusively in the hands of member states, this, together with the Blue Card, is the only directive to date that at least nominally aligns with the Commission's goal of significantly increasing the admission of third country labour migrants to the EU. Industries employing seasonal migrant labour (tourism, agriculture and horticulture are mentioned in the directive but member states are entitled to define additional ones) are by nature labour intensive, since cost can be kept at a minimum, and they have an obvious growth potential given the pull of high unemployment of unskilled labour in countries close to the EU.

58. As a partial solution to the problem of high unemployment in North African countries and elsewhere, the Commission has, within the framework of GAMM (as discussed above), made repeated calls for a better migration management in the Mediterranean and for more legal migration channels to the EU. The directive fits with this objective by being the first one to be promoted in terms of circular migration and by being specifically designed to support development and prevent 'illegal immigration' and employers' exploitation of TCNs through a set of 'fair and transparent rules for admission and stay'. In turn, these are intended to work legalizing on work in industries heavily staffed by undocumented migrants. As part of this, the directive puts much emphasis on 'safeguards to prevent overstaying or temporary stay from becoming permanent' (see also the Commission's directive proposal, EC 2010b); and, as such, it is also adapted to the previously adopted Employers Sanctions Directive. ${ }^{26}$ As the European Parliament's (2014) press release highlighted upon the passing of the directive, the rules established 'aim both to end exploitation and to prevent temporary stays becoming permanent'.

59. Aside from the treaty competence under Article 79(2), the directive, as outlined in the extensive preamble, is based on a number of EU migration policy aims and commitments, including the Hague Programme's call for measures to meet 'fluctuating demands for migrant labour'; the European Council's (of December 2006) request to examine measures to stimulate temporary migration; the European Pact on Immigration's goal (agreed in 2008) of 'proper management of migration flows' in cooperation with third countries; and, not the least, the Stockholm Programme's recognition of the importance of ELM in responding to demographic challenges and labour shortages and hence ELM's 'important contribution to the Union's economic development and performance in the long term'.

60. While taking note of 'fair treatment' of TCNs and while granting a set of minimum basic rights to seasonal workers (encompassing e.g. equal treatment in the areas of working conditions, terms of employment, working hours, pay and dismissal, minimum working age, health and safety requirements, freedom of association and the right to strike), the directive's rights provisions also differ significantly from most of the other EU directives relating to ELM. For instance, and due to member states' preferences, the directive does not provide for intra-EU mobility, something that facilitated the adoption process (Lazarowicz 2014: 1). In addition, it does not grant family reunification and it limits equal treatment in a number of areas, restraints that NGOs lobbied against during the negotiation period (see e.g. Joint NGO

25 Directive 2014/36/EU of the European Parliament and of the Council of 26 February 2014 on the conditions of entry and stay of third-country nationals for the purpose of employment as seasonal workers. The UK, Ireland and Denmark do not take part in this directive.

Directive 2009/52/EC of the European Parliament and of the Council of 18 June 2009 providing for minimum standards on sanctions and measures against employers of illegally staying third-country nationals. 
Statement 2011). This is obviously due to the temporary nature of seasonal work (see EC 2013c) but nevertheless underscores the stratifying effects of the sectoral approach to ELM.

61. For the same reason, and also in contrast to other ELM directives, there is no mention of migrant 'integration' in this directive. The absence of an integration endorsement can also be construed as contingent on the fact that the migrant labour addressed in this directive will enter highly segregated labour markets that, as the Commission has underscored time and again, face a permanent and growing 'structural need for low-skilled and low-qualified workers' that cannot be satisfied by 'EU national workers, primarily owing to the fact that these workers consider seasonal work unattractive' (EC 2010b: 2-3). If this explains the non-appearance of references to migrant integration in the directive, their absence as well as the Commission's sanction of segregated labour markets nonetheless contradict sharply with the Commission's overall emphasis on the crucial importance of migrants' successful integration into EU host societies. As the Commission (2005a: 4) has stated on numerous occasions: 'Admission of economic immigrants is inseparable from measures on integration'.

62. As with the other directives discussed here, finally, due mainly to Council resistance this directive also fails to meet the harmonization goals set up initially. Many of the administrative components related to admission, for instance, are to be kept within the purview of the member states, and the directive allows for a number of different admission terms, partly to avoid conflict with the Schengen acquis. In addition, and yet again in conformity with the other directives, the directive excludes a number of categories of third country nationals and it leaves much discretion to member states (see further Delaney 2013; Jonjić \& Mavrodi 2012; Monar 2013).

\section{The ICT Directive}

63. After some very difficult negotiations, lasting for four years, the Parliament and Council finally adopted the intra-corporate transferees directive (Dir. 2014/66/EU), laying down the terms of entry, residence and rights of third country managers, specialists and trainee employees who apply to be admitted as part of an intra-corporate transfer. ${ }^{27}$ By facilitating the entry and stay of ICTs (defined as temporary workers), ${ }^{28}$ the EU is to benefit from the added competence, skills, knowledge and innovation capacity that these migrants bring. In turn, this is to spur investment and benefit the knowledge-based economy. Besides treaty provisions authorizing a common migration policy, the ICT directive thus draws on the Europe 2020 strategy and its aims to have innovation and knowledge contribute more to economic growth. Once transposed (November 2016), the Commission expects the directive to apply to some 15-20 000 new ICTs annually.

64. The most contentious aspects of the proposal revolved around rights for the ICTs, in general, and intra-EU mobility rights, in particular. The Council insisted that ICTs should be placed on a par with posted workers, whereas the Parliament argued for equal treatment along similar lines as member state nationals (Monar 2013; Kostakopoulou, Acosta Arcarazo and Munk 2014: 144; Peers 2012b). However, as Peers (2012b: 105) has it, the Council and Parliament positions were 'not radically far apart' and in the end a compromise was finally struck. Here, and in accordance with the Council's position, it was agreed that 'Intra-corporate transferees should benefit from at least the same terms and conditions of employment as posted workers whose employer is established on the territory of the Union' (Article 15). At the same time, the Parliament managed to incorporate the right to equal treatment into many of areas (Brieskova 2014).

27

Directive 2014/66/EU of the European Parliament and of the Council of 15 May 2014 on the conditions of entry and residence of third-country nationals in the framework of an intra-corporate transfer. The UK, Ireland and Denmark do not take part in this directive.

The maximum duration of stay is limited to three years for managers and experts and one year for trainee employees. 
65. During the negotiations the European Trade Union Confederation (ETUC) argued that the rights framework for ICTs should be modelled on the Seasonal Workers Directive, not on posted workers; this to safeguard workers' protection and to prevent further fragmentation of the EU's labour market. As a result of the Council carrying the day on this issue, the directive's list of rights turned out to be quite short, including no more than three items. On the other hand, and in contrast to seasonal workers, ICTs were granted family reunification, although not to the same extent as the Parliament had wanted and as applies to third country workers in other directives. Also in contrast to seasonal workers, ICTs and their families were given intra-EU mobility rights. However, this came with many strings attached as the Council prevailed over the Parliament's request for less member state discretion in this area. Together with numerous other derogations, highly complex rules and much leeway for the member states, this diminishes the directive's harmonisation effect. 


\section{CONCLUSION}

66. Judged by the European Commission's yardstick of what needs to be done in order to enable a large-scale increase of ELM, the EU policies and legislation enacted over the past 15 years are nothing short of disappointing; and the first to acknowledge this is the Commission itself. As the then Home Affairs Commissioner put it in an interview in 2013, when referring to the necessity of stimulating labour migration: 'But it is politically impossible to attain in today's Europe' (quoted in Larsson 2013). Malmström is here foremost referring to the Commission's most favoured approach, namely the horizontal one of broad, supranational and thus harmonized rules, with as little differentiation as possible. But as shown in this paper, with the horizontal approach effectively discarded already in 2001, the Commission has instead spent the last decade pursuing a piecemeal sectoral approach that it never trusted in the first place. And given the great amount of discretion that the member states have managed to secure in each and every directive adopted so far, such lack of confidence is only natural; it is borne out of the experience of seeing each sectoral directive not even fulfilling its primary objective of generating a fair amount of harmonization in the targeted sector. As seen too, the sectoral approach has also compromised many of the Commission's original objectives, not least concerning transparency, rights and equal treatment of TCNs.

67. However, measured by another, less technocratic and more realistic, standard, the development accounted for here may well appear as both less disappointing and less irrational. Less disappointing because, given the political and economic realities on the ground, the likelihood of erecting an ELM regime even modestly resembling the one advocated by the Commission has always been slim at best. Moreover, what was very difficult to achieve with 15 members has not become easier with 28 members, all with highly diverse labour needs, unemployment levels, industrial structures, welfare regimes, positions in the business cycle and political leanings. Even if the member states were all in agreement with Brussels' goal of a massively increasing ELM, which many of them are in principle, these factors would still constitute a significant obstacle to getting agreement on supranational harmonization. In addition, several member states have invested quite some efforts in getting their own ELM policies up and running (as acknowledged by the Commission in its assessment of the Blue Card directive) and so have little inclination to scrap these for EU policies that may be less sensitive to national interests. To illustrate a bit further, recent Eurostat figures may be instructive. They show that EU member states 'issued around 2,36 million first residence permits to third country nationals in 2013', a 12 per cent increase as compared to 2012. Of these residence permits, 23 per cent were specifically issued for employment purposes. Somewhat contrary to what the 'demographic deficit' debate often gives at hand, these figures show that 'legal' third country immigration to the EU is far from insignificant. Yet when this data are disaggregated to the member state level it is also possible to discern a highly varied picture, both number-wise and proportionally speaking, with, for instance, six member states accounting for about 80 per cent of the total issuing of new residence permits to TCNs (Eurostat 2014). This thus reflects country specific preferences that, together with the current crisis, high unemployment and a range of other factors, speak to the fact that as long as enough member states feel they have more to gain from staying in control of ELM, they will only allow for so much common EU policy and legislation. 
68. While this should be quite straightforward and while the Commission seems to concede the reality of political obstacles, the bigger demographic-economic picture should still, according to the Commission, trump political differences and have governments come to their senses and embrace ELM for what it truly is: an economic survival strategy for the EU. This differs from how the Commission reasoned 15 years ago, when ELM was considered as just one important component in a broader policy mix to offset future demographic imbalances. Today, however, ELM is increasingly put forth as the primary remedy for the projected demographic decline. And as with all technocratic solutions or rationales also this one tends to relegate uncertainties, opposition and reservations to the realm of irrationality and false consciousness. The problem is though, that short of a full-fledged technocracy things such as demographic projections will not be able to dictate policy, but rather have to coexist and compete with a multitude of other interestmediated projections and policy options. What can be fairly certain though, is that a failure to orchestrate a large-scale ELM to the EU over the next 10-50 years will not necessarily spell catastrophe. To argue as such would be to underestimate socio-political inventiveness, technological advances and human agency; and it would also be to grossly overestimate the predictive power of demographic data. A host of unforeseen events and dislocations always tend to modify and sometimes upset the particular future course that seemed most likely at the outset.

69. The current crises in the EU can be seen as such unforeseen dislocations that few predicted; and it has also transformed migration policies and migration patterns (some of them quite dramatic) in ways few could have imagined prior to the crisis. Although the EU's current refugee crisis falls outside the scope of this paper, it is should be mentioned that it has had a significant demographic impact in some member states, most notably in Germany and Sweden, where it has also impacted positively on economic growth. In addition, it has of course also ignited policy discussions over how refugees could help resolve current and future labour shortages in the light of a declining working age population (see e.g. Hansen 2016; IMF 2016; OECD 2015; Statistics Sweden 2016).

70. Conversely, as of 2012, eleven member states, all of them severely affected by the economic crisis, suffered from net emigration (Eurostat 2013a; 2013b). According to the EU's most recent 'Ageing Report' from 2015, this number has now risen to thirteen, a striking development given that some of these countries were solid immigration countries before the crisis and expected to remain as such for the decades to come. Meanwhile, some member states that have weathered the crisis better have experienced a significant increase in labour immigration (e.g. Germany), much of it originating from other EU countries. ${ }^{29}$

With such crisis-induced migration from poorer to richer member states, the EU's migration debate is now not only targeting external migration and third country migrants but has increasingly come to target also the (free) movement of EU citizens themselves. More and more, then, a formerly commended free movement of EU citizens is being recast as a detrimental immigration of the poor, unemployed and, as some disparagingly calls it, welfare tourists. Accordingly, many EU members at the centre are now calling for restrictions on free movement from the peripheral members, requesting, above all, a curtailment of the social provisions that until now have formed an integral part of the EU's free movement regime. In the summer of 2013, for instance, Austria, Britain, Germany and the Netherlands wrote a joint letter to the Irish presidency, the Commission and the other member states, calling for the system be overhauled, emphasising that 'the right of EU citizens to freedom of movement is not unconditional', and also requesting that '[a]ll necessary measures need to be taken to deal with the consequences of this type of immigration and to fight its causes', including 'legal as well as financial measures.' (Letter to Mr Alan Shatter, President of the European Council for Justice and Home Affairs 2013). Given that this could jeopardize a long-standing regime that the Commission deems absolutely central not only for labour mobility but also for the EU project as such, it has caused a great deal of concern within the Commission and elsewhere. Indeed, since the letter dispute the situation has deteriorated further and the issue of free movement (or 'EU migration') has now become so contentious that Britain's membership in the EU (now the subject of a referendum in June 2016) may very well come to hinge on it. 
71. Since emigration may provide short-term fiscal relief - as the population eligible for social and unemployment benefits decreases - some governments obviously cannot afford the luxury of worrying too much about it. But from the Commission's perspective this should be a very worrisome development, spelling a worsening demographic decline in many member states while also accelerating demographic and labour imbalances in the Union as a whole, imbalances that may be very hard to reverse given that they mirror and are caused by the overall macroeconomic imbalances in the EU. The tendency, discerned in some member states, where many young unemployed, and often skilled, also emigrate to non-EU countries as a result of the crisis should be a cause of concern too. As with third country nationals leaving the EU due to the crisis, it deprives the Union of both skilled labour and working age people and thus belies the central objectives of the Commission's labour migration policy.

72. In the wake of the crisis, several EU governments' anti-immigration measures and rhetoric also run counter to the Commission's line of policy. Such measures include steps to either stop completely or curtail regular labour migration, further tightening of family migration, as well as social benefits and access to residence permits and some governments have sought to make unemployed migrants on temporary permits leave their countries.

73. This is yet another great obstacle to the Commission's ELM objectives, one that may explain why member states do not put priority of increasing and harmonizing ELM at this point in time. Yet, the crisis has not modified the Commission's stance. If anything it has rather served to reinforce the technocratic rationale further, or as argued by the Commission in its ' 3 rd Annual Report on Immigration and Asylum':

At first sight, the EU's current economic challenges might make it difficult to understand the necessity for legal migration and mobility channels. But it is necessary to bear in mind that, even with the overall EU unemployment rate of around 10\%, equating to 23.8 million citizens, and increasing to $22.1 \%$ for youths (under 25), many Member States are already experiencing labour and skills shortages in different sectors and for varying reasons. [...] Economic migration thus remains an important component part of efforts to address the challenges of labour shortages, notably in the context of the EU's ageing population and an increasingly competitive international market for talent, with other countries outside Europe also experiencing skills shortages. (EC 2012b: 4; see also Malmström 2012)

74. When the Commission states that it 'might make it difficult to understand the necessity for legal migration' this illustrates quite well the conflict between a technocratic approach, drawing on seemingly irrefutable facts about future problems and the necessary measures needed to resolve them, on the one side, and a political approach, drawing on expedient political calculations, public opinion and constraints imposed by the current political, economic and ideological leanings and realities on the ground.

75. It is no wild guess to assume that this conflict will continue to pervade EU policy on ELM. Judging from the European Council meeting in June 2014 and its 'strategic guidelines for legislative and operational planning for the coming years within the area of freedom, security and justice' there are no signs that the member states are ready to reconsider and allow for more EU influence over ELM (European Council 2014). As for the Commission, however, its recent announcements may indicate a change of course. Instead of new legislative initiatives the Commission has clarified that the focus from now on should be on ensuring implementation and consolidation of existing legislation and frameworks (EC 2014e). Many of the directives relating to ELM have just recently been transposed and some are still pending transposition. In this sense their real impact have not been tested yet. Instead of asking for the moon, then, the Commission's latest strategy may therefore be to focus its energies on making the most of what it has already managed to achieve. 


\section{REFERENCES}

Barber, T. (2011) ‘A line to hold', Financial Times, 15 June.

Brieskova, L. (2014) 'The new Directive on intra-corporate transferees: Will it enhance protection of thirdcountry nationals and ensure EU competitiveness?', EU Law Analysis: Expert insight into EU law developments, http://eulawanalysis.blogspot.se/2014/11/the-new-directive-on-intra-corporate.html

Brinkmann, G. (2012) 'Opinion of Germany on the Single Permit Proposal', European Journal of Migration and Law, 14: 351-66.

Carrera, S. and Hernández i Sagrera, R. (2009) 'The Externalization of the EU's Labour Immigration Policy', CEPS Working Document, 321.

Cassarino, J-P. (2008) 'Patterns of Circular Migration in the Euro-Mediterranean Area: Implications for Policy-Making', CARIM Analytic and Synthetic Notes 2008/29, Circular Migration Series, Florence: European University Institute.

Cerna, L. (2014) 'The EU Blue Card: preferences, policies, and negotiations between Member States', Migration Studies, 2(1): 73-96.

Chou, M-H. (2012) 'Constructing an internal market for research through sectoral and lateral strategies: layering, the European Commission and the fifth freedom', Journal of European Public Policy, 19(7): 1052-70.

Council EU (2004a) '2618th Council Meeting: Justice and Home Affairs', C/04/321, 14615/04 (Presse 321), Brussels, 19 November.

Council EU (2004b)'Presidency Conclusions', Brussels European Council 4-5 November 2004, 14292/1/04, Brussels, 8 December.

Council EU (2008) 'European Pact on immigration and asylum', 13440/08, 24 September.

Council EU (2012) 'Draft Council Conclusions on the Global Approach to Migration and Mobility', 8361/12, Brussels, 30 March.

Delaney, E. F. (2013) 'Justifying Power: Federalism, Immigration, and Foreign Affairs', Duke Journal of Constitutional Law \& and Public Policy, 8(1): 153-95.

Douglas-Scott, S. (2011) 'The European Union and Human Rights after the Treaty of Lisbon', Human Rights Law Review, 11(4), pp. 645-82.

Eisele, K. (2013) 'Why come here if I can go there? Assessing the "Attractiveness" of the EU's Blue Card Directive for "Highly Qualified" Immigrants', CEPS Paper in Liberty and Security in Europe, No. 60.

EC (European Commission) (1976 [1974]) 'Action programme in favour of migrant workers and their families', $\operatorname{COM}(74)$ 2250, 14. 12, Bulletin of the EC, Suppl. 3/76. 


\section{DELSA/ELSA/WD/SEM(2016)11}

EC (European Commission) (1994) 'On immigration and asylum policies', COM(94) 23 final, Brussels, 23. 2.

EC (European Commission) (1996) Europe ... questions and answers: The European Union - What's in it for me? Luxembourg: Office for Official Publications of the EC.

EC (European Commission) (1999) 'Proposal for a Council Directive on the right to family reunification', COM(1999) 638 final, Brussels, 1. 12.

EC (European Commission) (2000) 'On a Community Immigration Policy', COM(2000) 757 final, Brussels, 22. 11.

EC (European Commission) (2001a) 'Proposal for a Council Directive concerning the status of thirdcountry nationals who are long-term residents', $\operatorname{COM}(2001) 127$ final, Brussels, 13. 3.

EC (European Commission) (2001b) 'Proposal for a Council directive on the conditions of entry and residence of third-country nationals for the purpose of paid employment and self-employed economic activities', $\operatorname{COM}(2001) 386$ final, Brussels, 11. 7.

EC (European Commission) (2002) 'Green Paper on a Community Return Policy on Illegal Residents', $\operatorname{COM}(2002) 175$ final, Brussels, 10. 4.

EC (European Commission) (2005a) 'Policy Plan on Legal Migration', COM(2005) 669 final, Brussels 21. 12.

EC (European Commission) (2005b) 'Green Paper on an EU Approach to Managing Economic Migration', $\operatorname{COM}(2004) 811$ final, Brussels 11. 1.

EC (European Commission) (2005c) 'A Common Agenda for Integration: Framework for the Integration of Third-Country Nationals in the European Union', COM(2005) 389 final, Brussels, 1. 9.

EC (European Commission) (2007a) 'Attractive conditions for the admission and residence of highly qualified immigrants', MEMO/07/423, Brussels, 23 October.

EC (European Commission) (2007b) 'Proposal for a Council Directive on the conditions of entry and residence of third-country nationals for the purposes of highly qualified employment', $\operatorname{COM}(2007)$ 637final, Brussels, 23. 10.

EC (European Commission) (2007c) 'On circular migration and mobility partnerships between the European Union and third countries', $\operatorname{COM(2007)} 248$ final, Brussels, 16. 5.

EC (European Commission) (2007d) 'Proposal for a Council Directive on a single application procedure for a single permit for third-country nationals to reside and work in the territory of a Member State and a common set of rights for third-country workers legally residing in a Member State', $\operatorname{COM}(2007) 638$ final, 23. 10.

EC (European Commission) (2010a) 'EUROPE 2020: A strategy for smart, sustainable and inclusive growth', $\operatorname{COM(2010)} 2020$ final, Brussels, 3. 3.

EC (European Commission) (2010b) 'Proposal for a directive [...] on the conditions of entry and residence of third-country nationals for the purpose of seasonal employment', $\operatorname{COM}(2010) 379$ final, Brussels, 13. 7 . 
EC (European Commission) (2011a) 'Communication on migration', COM(2011) 248 final, Brussels, 4. 5.

EC (European Commission) (2011b) 'The Global Approach to Migration and Mobility', COM(2011) 743 final, Brussels, 18. 11.

EC (European Commission) (2011c) 'A dialogue for migration, mobility and security with the southern Mediterranean countries', COM(2011) 292 final, Brussels, 24. 5.

EC (European Commission) (2011d) 'European Agenda for the Integration of Third-Country Nationals', $\operatorname{COM}(2011) 455$ final, Brussels, 20. 7.

EC (European Commission) (2011e) 'Report from the Commission to the European Parliament and the Council on the application of Directive 2004/114/EC on the conditions of admission of third-country nationals for the purposes of studies, pupil exchange, unremunerated training or voluntary service', $\operatorname{COM}(2011) 587$ final, Brussels, 28. 9.

EC (European Commission) (2011f) 'Report from the Commission to the Council and the European Parliament on the application of Directive 2005/71/EC on a specific procedure for admitting thirdcountry nationals for the purposes of scientific research', $\operatorname{COM}(2011) 901$ final, Brussels, 20. 12.

EC (European Commission) (2011g) 'Migration and Development', accompanying the document 'The Global Approach to Migration and Mobility' (COM(2011) 743 final), SEC(2011) 1352 final, Brussels, 18. 11.

EC (European Commission) (2012a) 'The 2012 Ageing Report: Economic and budgetary projections for the 27 EU Member States (2010-2060)', European Economy 2/2012, DG Economic and Financial Affairs.

EC (European Commission) (2012b) '3rd Annual Report on Immigration and Asylum', COM(2012) 250 final, Brussels, 30. 5.

EC (European Commission) (2013a) 'Maximising the Development Impact of Migration: The EU contribution for the UN High-level Dialogue', COM(2013) 292 final, Brussels, 21. 5.

EC (European Commission) (2013b) 'Proposal for a directive of the European Parliament and of the Council on the conditions of entry and residence of third-country nationals for the purposes of research, studies, pupil exchange, remunerated and unremunerated training, voluntary service and au pairing', $\operatorname{COM(2013)~} 151$ final, Brussels, 25. 3.

EC (European Commission) (2013c) 'Cecilia Malmström welcomes agreement on migrant seasonal workers', Memo/13/941, Brussels, 29 October.

EC (European Commission) (2013d) 'On the work of the Task Force Mediterranean', COM(2013) 869 final, Brussels, 4. 12.

EC (European Commission) (2014a) ‘On EU Return Policy', COM(2014) 199 final, Brussels, 28. 3.

EC (European Commission) (2014b) '5th Annual Report on Immigration and Asylum (2013)', $\operatorname{COM}(2014) 288$ final, Brussels, 22. 5. 


\section{DELSA/ELSA/WD/SEM(2016)11}

EC (European Commission) (2014c) 'On the implementation of Directive 2009/50/EC on the conditions of entry and residence of third-country nationals for the purpose of highly qualified employment', $\operatorname{COM}(2014) 287$ final, Brussels, 22. 5.

EC (European Commission) (2014d) 'Report on the Implementation of the Global Approach to Migration and Mobility 2012-2013’, COM(2014) 96 final, Brussels, 21. 2.

EC (European Commission) (2014e) 'An open and secure Europe: making it happen', COM(2014) 154 final, Brussels, 11. 3.

EC (European Commission) (2015) 'The 2015 Ageing Report: Economic and budgetary projections for the 28 EU Member States (2013-2060)', DG Economic and Financial Affairs.

European Council (1999) 'Presidency Conclusions Tampere European Council’, 15-16 October.

European Council (2014) ‘Conclusions’, EUCO 79/14, CO EUR 4, CONCL 2, Brussels, 27 June.

European Economic and Social Committee (2005) 'Opinion of the European Economic and Social Committee on the Green paper on an EU approach to managing economic migration', SOC/199, Brussels, 9 June.

European Parliament (1990) 'Report drawn up on behalf of the Committee of Inquiry into Racism and Xenophobia', Session Documents, Doc. A3-195/90, Brussels-Luxembourg, 23. 7.

European Parliament (2005) European Parliament resolution on an EU approach to managing economic migration(COM(2004)0811 - 2005/2059(INI)), P6 TA(2005)0408, Economic migration.

European Parliament (2014) 'More rights and better working conditions for non-EU seasonal workers', Plenary Session, Press release, 5 February.

Eurostat (2013a) 'Migration and migrant population statistics', March, http://epp.eurostat.ec.europa.eu/statistics_explained/index.php/Migration_and_migrant_population_s tatistics.

Eurostat (2013b) Eurostat News release, 173/2013, 20 November, http://epp.eurostat.ec.europa.eu/cache/ITY_PUBLIC/3-20112013-AP/EN/3-20112013-AP-EN.PDF.

Eurostat (2014) Residence permits statistics, October, http://ec.europa.eu/eurostat/statisticsexplained/index.php/Residence_permits_statistics.

Feldman, G. (2012) The Migration Apparatus: Security, Labour, and Policymaking in the European Union, Stanford: Stanford University Press.

Geddes, A. (2000) Immigration and European Integration: Towards Fortress Europe?, Manchester: Manchester University Press.

Goldirova, R. (2008) 'MEPs back foreign worker 'Blue Card' plan',EUobserver.com, 21 November (http://euobserver.com/9/27155).

Groenendijk, K. (2013) 'Social Assistance and Social Security for Lawfully Resident Third-Country Nationals: On the Road to Citizenship?', in Guild, E., Carrera, S. and Eisele, K. (eds), Social 
Benefits and Migration: A Contested Relationship and Policy Challenge in the EU, Brussels: Centre for European Policy Studies (CEPS).

Grütters, C. and T. Strik (eds) (2013) The Blue Card Directive: Central Themes, Problem Issues, and Implementation in Selected Member States, Oisterwijk: Wolf Legal Publishers.

Gümüs, Y. K. (2010) 'EU Blue Card Scheme: The Right Step in the Right Direction?', European Journal of Migration and Law, 12: 435-53.

Hailbronner, K. (1998) 'European immigration and asylum law under the Amsterdam Treaty', Common Market Law Review, 35: 1047-67.

Hansen, P. (2016) 'Anyone for Refugee Keynesianism? Refugee Surplus and Demographic Deficit in Times of Fiscal Austerity', in S. Jonsson and J. Willen (eds), Austere Histories in European Societies: Social Exclusion and the Contest of Colonial Memories, London: Routledge (forthcoming September).

Hansen, P. and Hager, S. B. (2012) The Politics of European Citizenship: Deepening Contradictions in Social Rights and Migration Policy, New York: Berghahn Books.

Hedemann-Robinson, M. (1999) 'The Area of Freedom, Security and Justice with Regard to the UK, Ireland and Denmark: The "Opt-in Opt-outs" under the Treaty of Amsterdam', in D. O'Keeffe and P. Twomey (eds), Legal Issues of the Amsterdam Treaty, Oxford: Hart Publishing.

IMF (2016) 'The Refugee Surge in Europe: Economic Challenges', IMF Staff Discussion Note, January, $\mathrm{SDN} / 16 / 02$.

Joint NGO Statement (2011) 'EU Seasonal Migrant Workers' Directive: Full Respect of Equal Treatment Necessary', 20 April, http://lastradainternational.org/lsidocs/joint\%20ngo\%20statement.pdf.

Jonjić, T. and Mavrodi, G. (2012) 'Immigration in the EU: policies and politics in times of crisis 20072012', EUDO Report 2012/5, European Union Democracy Observatory, Robert Schuman Centre for Advanced Studies, Florence.

Kostakopoulou, T. 2002. 'Long-term resident third country nationals in the European Union: normative expectations and institutional openings', Journal of Ethnic and Migration Studies, 28(3): 443-62.

Kostakopoulou, D., Acosta Arcarazo, D. and Munk, T. (2014) 'EU Migration Law: The Opportunities and Challenges Ahead', in Kostakopoulou, D., Acosta Arcarazo, D. and Munk, T. (eds), EU Security and Justice Law: After Lisbon and Stockolm, Oxford: Hart.

Larsson, E. (2013) “'Om du har ett jobb borde du få komma in i EU”' (Interview with Cecilia Malmström), Arbetet, 15 March, http://arbetet.se/2013/03/15/om-du-har-ett-jobb-borde-du-fa-komma-in-i-eu/ (accessed 23 August 2014).

Lazarowicz, A. (2014) 'A success for the EU and seasonal workers' rights without reinventing the wheel', Policy Brief, 28 March, European Policy Centre, Brussels.

Letter to Mr Alan Shatter, President of the European Council for Justice and Home Affairs (2013) 15 April, http://docs.dpaq.de/3604-130415_letter_to_presidency_final_1_2.pdf. 


\section{DELSA/ELSA/WD/SEM(2016)11}

Malmström, C. (2010) 'Malmström proposes EU coordination of labour migration', 13 July (http://ec.europa.eu/commission_2010-2014/malmstrom/news/archives_2010_en.htm).

Malmström, C. (2012) 'Statement by EU Commissioner Cecilia Malmström onInternational Migrants Day’, Memo/12/1003.

Monar, J. (2013) 'Justice and Home Affairs', Journal of Common market Studies, 51(Annual Review): 124-38.

OECD (2015) Migration Policy Debates, No. 8, November.

Pascouau, Y. and McLoughlin, S. (2012) 'EU Single Permit Directive: a small step forward in EU migration policy, Policy Brief, 24 January, European Policy Centre, Brussels.

Peers, S. (2009) 'Legislative Update: EC Immigration and Asylum Law Attracting and Deterring Labour Migration: The Blue Card and Employer Sanctions Directives', European Journal of Migration and Law, 11: 387-426.

Peers, S. (2012a) 'Single Permits and Workers' Rights', in Peers, S., Guild, E., Acosta Arcarazo, D., Groenendijk, K. and Moreno-Lax, V. (eds), EU Immigration and Asylum Law (Text and Commentary): Second Revised Edition, Volume 2: EU Immigration Law, Leiden: Martinus Nijhoff.

Peers, S. (2012b) 'Intra-Corporate Transferees', in Peers, S., Guild, E., Acosta Arcarazo, D., Groenendijk, K. and Moreno-Lax, V. (eds), EU Immigration and Asylum Law (Text and Commentary): Second Revised Edition, Volume 2: EU Immigration Law, Leiden: Martinus Nijhoff.

Statistics Sweden (2016) Sveriges ekonomi, No. 1.

Triandafyllidou, Anna (ed.) (2013) Circular Migration between Europe and its Neighbourhood: Choice or Necessity?, Oxford: Oxford University Press.

Venturini, A. (2008) 'Circular Migration as an Employment Strategy for Mediterranean Countries', CARIM Analytic and Synthetic Notes, 2008/39, Florence: European University Institute. 